\title{
Modernliğin Müphem Öznelliği Çerçevesinde Bukalemun İnsan Zelig
}

\author{
Deniz Kurtyılmaz*
}

\section{Özet}

Hümanist Giovanni Pico della Mirandola, 1496 tarihli İnsanın Değeri Üzerine Söylev adlı eserinde, insanın ne isterse o olmak konusunda sinırsızca özgür olduğunu müjdelerken modern öznelliğin parolasını da vermektedir. Modern olmak, evvela birey olarak özgürleşmek; tüm dış yetkelerden bağımsızlık talep etmek konusunda cesur bir öznelliği düşlemek anlamına gelir. Zygmunt Bauman da Rönesans boyunca "bukalemun-insan" imgesinin bıkkınlık verici ölçüde vurgulandiğını söylerken, modernliğin ilk icadının istediği varoluş biçiminde yaşamını sürdürme hürriyeti kazanmış bir özne fikri olduğunu ifade etmektedir. Ancak, zaman içindeki serüveni incelendiğinde, modern öznelliğin bir paradoks taşıdığı görülür: Birey, radikal bir özgürlük talebiyle tüm bă̆larından koparak kendi kendini yaratacak, fakat ayn birey, tam da bu özgürleşme sürecinde, varlığına anlam katan maddi (sosyal) ve manevi (metafizik) ölçüleri yitirecektir. Birey olmak konusunda hür olan modern insan, bunun ne anlama geldiği hususunda bir kafa karışıliğından mustarip olduğundan, öngörüldüğünün aksine, sağlıkh bir öznellik inşa edememektedir. Bu bağlamda, Woody Allen'ın 1983 tarihli Zelig filmi bahsedilen krizin oldukça iyi biçimde karikatürize edilmiş bir yansımasını izleyicisine sunmaktadır. Filme adın veren Leonard Zelig, kimin yanında birkaç dakikadan fazla kalsa fiziksel ve ruhsal anlamda ona benzemeye başlayan bir figür; modernliğin müphemliğine dair bir hiciv olarak karşımıza çıkmaktadır. Üstelik müphemlik içerikle sınırlı kalmayarak filmin anlatısına da sirayet etmiştir. Allen'ın eseri bir "mockumentary" olması dolayısıyla gerçek ve kurgu arasındaki sinırlar da bulanıklaştıran "göçebe" bir biçeme sahiptir. Filmi, modern öznelliğin müphemliği konusu temelinde felsefi bir incelemeye tabi tutmayı amaçlayan çalışmamız eseri yapısöküme uğratarak modern/çă̆daş insana dair çıkarmmlar yapacaktır.

Anahtar kelimeler: Woody Allen, Zelig, modernlik, birey, müphemlik.

*ORCID: 0000 - 0001 - 8123 - 8034

E-mail: denizkurtyilmaz@hotmail.com

DOI: 10.31122 /sinefilozofi.680704

Geliş Tarihi - Recieved: 15.01.2020

Kabul Tarihi - Accepted: 01.05.2020

\footnotetext{
${ }^{1}$ Bu bildirinin teorik çerçevesi, büyük ölçüde, 2016 yılında Selçuk Üniversitesi Sosyal Bilimler Enstitüsü, Radyo Televizyon ve Sinema Anabilim Dalı'nda tamamlanan “Birey, Kitle ve İletişim Teknolojileri: Tarihsel Sürece Eleştirel Bir Bakış" adlı yüksek lisans tezimize dayanmaktadır
} 


\title{
The Chameleon Man Zelig in the Frame of the Ambivalent Subjectivity of Modernity ${ }^{2}$
}

\author{
Deniz Kurtyılmaz*
}

\section{Abstract}

In his Oration on the Dignity of Man, published in 1496, humanist Giovanni Pico della Mirandola deciphered the enigma of modern subjectivity when he heralded that Man is infinitely free to be whatever he chooses to be. Indeed, to be modern, at first, is to be liberated as an individual, which means dreaming to produce a bold subjectivity by demanding independence from all external powers. Zygmunt Bauman also addresses that during the Renaissance, the image of the "chameleon-man" has been stressed to an excruciating extent basically to state the first invention of modernity, the idea of a subject who has gained the freedom to live in one's own chosen form of existence. However, if the process of its historical evolution is examined, it becomes clear that modern subjectivity carries a paradox in itself. On the one hand, the individual will only be able to create himself by breaking away from all ties with a radical demand for freedom; but, on the other hand, in so doing, the same individual will also inevitably lose his material (social) and spiritual (metaphysical) principle and values that add meaning to his existence. The modern man, who is free to be a self-made individual, suffers from a confusion as to what this means and cannot build a healthy subjectivity contrary to expectations. In this context, Woody Allen's film Zelig (1983) presents a well-caricatured reflection of this crisis. Leonard Zelig, who gave his name to the film, appears as a satire of the modern ambivalence as a figure who begins to resemble others both physically and psychologically when he stays with them for more than a few minutes. Moreover, the ambivalence is not limited to the content but also spreads to the narrative of the film. Since Allen's work is a mockumentary, it has a "nomadic" form that blurs the boundaries between reality and fiction. Our study, which aims to subject the film to a philosophical examination on the basis of the ambivalence of modern subjectivity, will deconstruct the work and make inferences about the modern/contemporary individual.

Keywords: Woody Allen, Zelig, modernity, individual, ambivalence.

\footnotetext{
*ORCID: 0000 - 0001 - 8123 - 8034

E-mail: denizkurtyilmaz@hotmail.com

DOI: 10.31122/sinefilozofi.680704
}

Received - Geliş Tarihi: 15.02.2020

Accepted - Kabul Tarihi 01.05.2020

\footnotetext{
2 The theoretical framework of this paper is largely based on our master's thesis titled "Individual, Mass and Communication Technologies: A Critical Overview on Historical Process" which was completed in 2016 at the Department of Radio, Television and Cinema, Selcuk University Social Sciences Institute.
} 


\title{
Giriş
}

\begin{abstract}
"[Aydınlanma ile] insanlara benlikleri, tümüyle özgün ve herkesinkinden farklı bir benlik olarak armağan edilir ki, herkesinkiyle aynı olması iyice sağlama alınabilsin."
\end{abstract}

Theodor Adorno ve Marx Horkheimer

Bilindiği üzere modern dönemin başlaması ile birey'in doğuşu arasında belirgin bir bağ, hatta bir denklik vardır (Giddens, 2014: 102; Fromm, 2011: 48-49; Guenon, 1999: 90). Söz konusu denkliğin koşulladığı anlamıyla modern olmak, önce tüm bağlayıcı dışsal değer ve kurallardan bağımsızlaşan bir öznelliğe ulaşmak (Tarnas, 2011: 13), ardından varlık, bilgi ve değer alanlarını yalnızca bu öznellikten hareketle inşa etmek demektir (Küçükalp ve Cevizci, 2009: 116). Bu iki yönlü “hümanist metafizik” (Çotuksöken, 2002: 19) 17. yüzyılda Kartezyen cogito'nun ${ }^{3}$ modernliğin felsefi dayanağı olmasıyla zirveye ulaşmışsa da, ilk adımını Rönesans'tan itibaren somutlaşmaya başlayan bağımsız bir birey olma düşüncesiyle atmıştır (Cassirer, 2018: 167).

Örneğin, hümanist Giovanni Pico della Mirandola (1463 - 1494) insanın "ne isterse o olmak konusunda Tanrı'dan izinli olduğunu" (1496/1956: 8) söyleyerek bireyselliğini istediği şekliyle üretmesinin onun en kutsal hakkı olduğu vurguladığında tarih henüz 15. yüzyılın sonudur. Üstelik İtalyan düşünür yalnız değildir. Mirandola'nın pek çok çağdaşı da insanın dünyayı "kendi" gözleriyle görebilmesi için evvela kendisinin farkına varmasından ve değişmesinden; onu gerek maddi gerek manevi anlamda yükselmekten alıkoyan tüm bağlarından kurtularak kendisini sil baştan yaratma cesareti göstermesi gerektiğinden bahsetmiştir. Öyle ki, Zygmunt Bauman (1925 - 2017), bulunduğu her duruma adapte olma ve gerekirse kendini tepeden tırnağa değiştirme kabiliyetine vurgu yapacak şekilde, "bukalemun-insan" imgesinin dönemin düşünce dünyasında şaşırtıcı bir sıklıkla karşımıza çıktığını söylemektedir (Bauman, 2011a: 34-35; Bauman, 2011b: 176).

Demek ki, birey ve onun öznelliği, modern Kartezyen dünya tasarımının Arşimet noktası olmasından önce de insanın dışsal bir moral değere ya da toplumsal kurala bağlı olmaksızın kendi kimliğini özgürce inşa etme talebiyle öne çıkmaktadır (Levi, 2002: 80). Üstelik Kartezyen düalizmin 20. yüzyıldan bu yana değer kaybettiği; hatta bilimsel alanda tamamıla sona erdiği söylenen çağdaş dünyamızda bile söz konusu özgürlük talebi hâlâ tedavüldedir. ${ }^{4}$ Fakat böyle bir arzunun dolaşımda olması, onun tahakkuk ettiği anlamına gelmez. Aksine, tarihi seyrine baktı̆̆ımızda, insanın, kendisini kısıtlayan birçok dış yetkeden

3 “Cogito, ergo sum!” Descartes'ın 1637 tarihli Yöntem Üzerine Konuşma kitabında ifade ettiği ve “Düşünüyorum, o halde varım!" anlamına gelen cümledir. Bu argümantasyonu ile Descartes, düşünen öznenin kesinliği üzerine inşa edilmiş rasyonalist modern Batı felsefesinin kurucusu olarak görülmüştür.

4 Bağımsız maddi varlığı hakkında şüphe duyulmayan bir dış dünya ile onu bilmeye ve yasalarını keşfetmeye muktedir özne düalizmine dayalı Kartezyen bölünmeden hareket eden modern ussallık ve onun üzerine inşa edilmiş modern bilimin mekanikçi evren tasavvuru 20.yüzyılın başındaki gelişmeler sayesinde ciddi biçimde sorgulanır hale gelmiştir (Bu değişimi incelemek için bkz. İshak Arslan, Çağdaş Doğa Düşüncesi, İstanbul: Küre Yayınları). Buna karşın, bilimsel paradigmadaki değişimin kültürel alana etki ettiğini; modern bireyin özgürlük talebinde bir azalma olduğunu düşündürecek bir gelişmenin yaşandığını söylemek mümkün görünmemektedir. 
kurtulma fırsatı bulduğu açı olsa da, bir ölçü hâline gelemeden "buharlaşan" değerler ve alışabileceğinden daha hızlı değişen toplumsal yapı içinde (Berman, 2013) kendi kimliğini inşa etmek konusunda giderek artan bir güçlük yaşadığ gerçektir. Tecrübe ettiğimiz zorluk sebebiyle öznelliğimiz belirlenmek yerine müphemleşmektedir ${ }^{5}$.

Dolayısıyla, modern bireyin bir temsili olan bukalemun-insan'ın nasıl ve ne ölçüde ortaya çıkabildiği sorusu hâlihazırda önemli bir problem olarak karşımızda durmaktadır. Hatta denebilir ki bireye dönük tüm çağdaş tartışmalar onun özgürlük arayışı ve kimlik buhranı arasındaki denge(sizlik) etrafında şekillenmektedir. Sinema sanatı da kendi perspektifinden sunduğu manzaralarla bu tartışmalara katılmaktayken Amerikalı yönetmen Woody Allen'ın 1983 tarihli filmi Zelig, çağdaş insanın kimlik buhranını oldukça ironik bir biçimde ele almaktadır. Çalışmamız, Allen'ın filmini hem biçim hem de söylem bağlamında yapısöküme tabi tutarak modern insana ve yaşadığı öznellik krizine dair bazı düşünceler ortaya koymaya çalışacaktır.

\section{En Az Modern Öznelliğimiz Kadar Müphem Bir Film Biçemi: Mockumentary}

Yönetmenliğini ve senaryo yazarlığını Woody Allen'ın, görüntü yönetmenliğini ise Gordon Willis'in yaptığı filme adını veren kurgusal karakter Leonard Zelig6 (Woody Allen), 1920'lerin Amerika'sında yaşayan ve kimin yanında birkaç dakikadan fazla dursa hem fiziksel hem de ruhsal/psikolojik olarak ona benzemeye başlayan biridir. Hatta buna benzemek dahi denemez; Leonard her defasında başlı başına bir dönüşüm geçirmektedir. Beraber olduğu insana ya da içinde bulunduğu ortama kusursuz bir uyum gösterip bambaşka biri olup çıkan Zelig'in sabit/tutarlı denebilecek bir benliği bile kalmamıştır. İstemsiz gerçekleşen ve patolojik bir hal almış olan değişimler, medyanın da büyük bir ilgi göstermesiyle, her şeyin abartılı bir coşkuyla yaşandığı "kükreyen yirmiler"de (roaring twenties $)^{7}$ kamusal bir meseleye dönüşür ve halkın tek gündem maddesi haline gelir.

\footnotetext{
5 "Müphemlik" kavramı, tüm çalışma boyunca, Polonya asıllı sosyolog ve felsefeci Zygmunt Bauman'ın ona yüklediği anlamıyla kullanılmıştır. "Bir nesne ya da bir olayın birden fazla kategoriye sokulabilmesi olan müphemlik, dile özel bir düzensizliktir, yani dilin icra ettiği adlandırma (sınıflandırma) fonksiyonun iflası[dır]. Bu düzensizliğin temel belirtisi, belli bir durumu doğru biçimde okuyamadığımız ve alternatif eylemler arasında seçim yapamadığımız zaman hissettiğimiz keskin rahatsızlıktır" (Bauman, 2003: 9). Dolayısıyla müphemlik, anlamca, "açık seçik olmamak, belirsiz kalmak" kadar, ne kadar arzu etsek de bir türlü belirlenmiş bir duruma gelememeyi ve bundan duyulan kronik tedirginliği de ihtiva etmektedir.

6 Zelig ismi, Yidiş dilinde (Yiddish) "mutlu, kutsanmış, mübarek” anlamlarına gelen bir sözcük olarak Allen'ın karakterinin Eskenazi Yahudisi kökenlerine gönderme yaptığı kadar, manasının isim sahibinin durumuyla oluşturduğu tezatlık üzerinden bir ironiyi de ortaya koymaktadır. Daha da ilginci, Woody Allen'ın filminin ardından "zelig" sözcügüu, Yidiş dilindeki karşılığından bağımsız olarak, "aşırı uyumcu ya da oportünist insan, çeşitli ortamlarda şaşırtıcı şekilde veya sıklıkla ortaya çıkan sıradan, önemsiz bir kişi” manalarına gelecek şekilde İngilizceye de dahil edilmiştir (https://www.collinsdictionary.com/dictionary/english/zelig).

7 "Kükreyen yirmiler" terimi Kuzey Amerika ve Avrupa kıtasında I. Dünya Savaşı sonrası yaşanan, orta-üst sınıfa ait refah ve geleceğe dönük genel bir iyimserlik dönemini imleyen bir kavramdır. 1918 yılında başlatıp 1929’da yaşanan Büyük Buhran'la (Great Depression) sona eren "kükreyen yirmiler" inşaat ve otomobil sektöründeki devasa atılımlarla ivmelenen bir ekonomik gelişmeyle beraber; kitle iletişim araçlarının yaygınlaşmasıyla enformasyonun yerini sansasyonun, Fordizmin zaferiyle üretimin yerini tüketimin, bilim ve sanat alanında yaşanan gelişmelerin etkisiyle rasyonalitenin yerini irrasyonalizasyonun almaya başladığ (Ayrıntılı bir "kükreyen yirmiler" incelemesi için bkz. Tom Streissguth, The Roaring Twenties, New York: Facts on File Inc.). Filmin anlatıcı dış sesi, dönemi, çılgınca eğlenen insanların görüntüleri ve kalabalık şehir hayatı manzaraları eşliğinde şöyle tasvir etmektedir: "Yıl 1928. Amerika on yıl süren eşitsiz refahın tadını çıkartırken çıldırmış durumda. Jazz çağı... Böyle deniyor. Ritmler uyumsuz, ilişkiler daha rahat, eğer bulabilirseniz içki daha ucuz. Tuhaf kahramanların, çılgın dublörlerin, gizli eğlence mekânlarının ve gösterişli partilerin çağı..."
} 
Sansasyonel yeteneğine atfen kendisine "bukalemun-insan" (human chameleon) lakab1 verilen Zelig, bir yandan halkın büyük bir merakla takip ettiği popüler bir figür olarak giderek ünlenirken, diğer yandan yaşadığı olağan dışı dönüşümler sebebiyle uzmanlar tarafından bir akıl hastanesinde müşahede altına alınmasına karar verilen zavallı bir hasta olup çıkar. Leonard Zelig, esasında, kimsenin gerçek anlamda ilgi göstermediği; yalnızca kendi değerleri üzerinden yargıladığı ve bu sebeple kimsenin yardım eli uzatamadığı çaresiz bir adamdır. Kaldırıldığı hastanede kendisiyle karşılaşan psikiyatrist Dr. Eudora Fletcher (Mia Farrow) ise Zelig'i yalnızca tuhaf bir fenomen ya da sıradan bir hasta olarak görmenin ötesine geçerek Leonard'la özel bir bağ kuracak ve onu iyileştirmek için elinden gelen her şeyi yapacaktır.

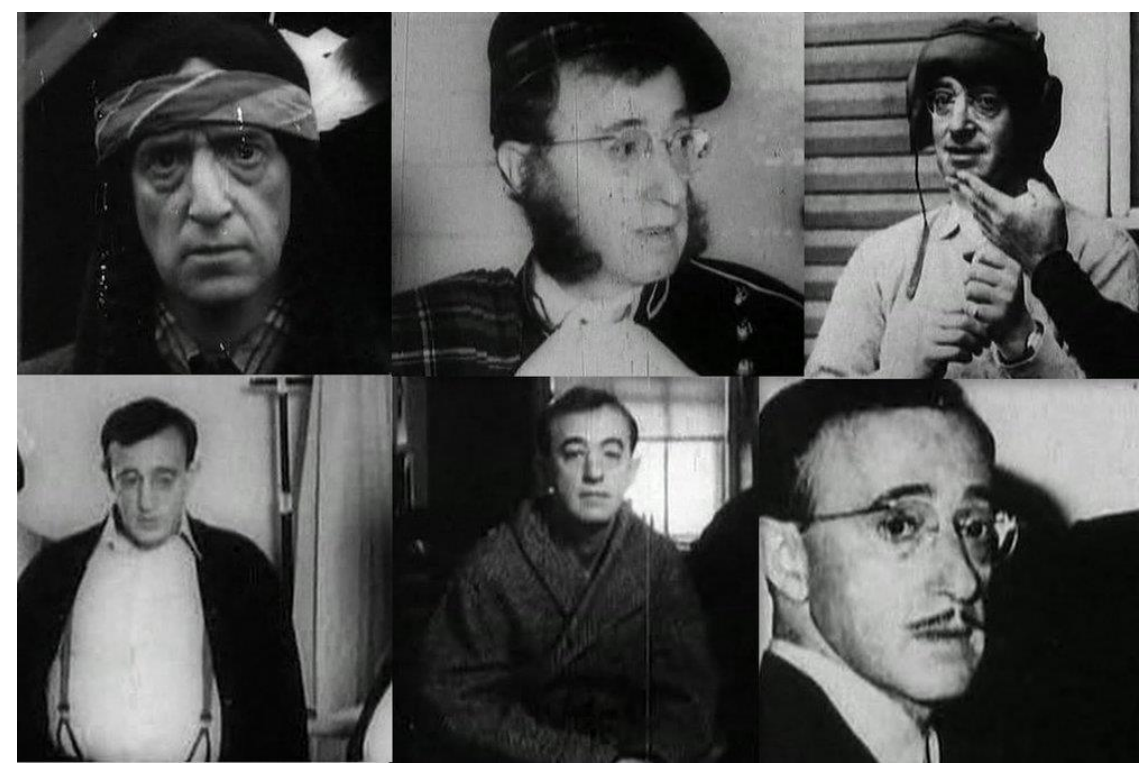

Görsel 1. Kılıktan kılı̆̆a girebilen Leonard Zelig

Öncelikle belirtilmelidir ki Zelig filmi kurmaca-belgesel/mokümanter (mockumentary) bir yapım olarak seyircisine biçimsel bir müphemlik sunmaktadır. Eğer Woody Allen'ın kendine özgü film stiline aşina değilse, izleyici ilk anda, 1900'lerin ilk yarısında yaşamış gerçek bir insana dair 1983 yapımı bir belgesel izlediği düşüncesine kapılmadan edemez. Zira Woody Allen'ın yapıtı, 20'lerin Amerika'sına ait gerçek görüntüler ve Leonard Zelig hakkındaki düşüncelerini paylaşan ünlü uzmanların ciddi beyanatlarıyla başlamaktadır. Hatta bunlardan da önce, film, "Az sonra izleyeceğiniz belgesel Dr. Eudora Fletcher, Paul Deghuee ve Bayan Meryl Fletcher Varney'e en içten teşekkürlerini sunar," yazısını prolog olarak kullanmak suretiyle hepimizi gerçek bir belgesel izleyeceğimiz konusunda ikna etmektedir.

Dolayısıyla, seyirci ancak filmin ilerleyen dakikalarında kendisini açık etmeye başlayan absürt hikâye sayesinde belgesel değil de kurmaca bir film izlediğinin farkına varabilmektedir. Fakat yine de eserin biçimsel müphemliği hiçbir zaman tam anlamıla ortadan kalkmaz. Tüm film boyunca gerçek görüntülerle kurmaca sahneler, görüntü 
yönetmeni Gordon Willis (1931 - 2014) tarafından öyle ustalıkla birleştirilmiştir ki ${ }^{8}$ izleyici, gördüğü çoğu sahnenin gerçek belgesel görüntülerden mi yoksa kurmaca yeniden çekimlerden mi oluştuğuna karar veremez duruma gelmektedir (Girgus, 2002: 90-91). Allen'ın yapıtı, tipik bir mokümanter film olarak, izleyiciye gerçeklik vaat etmemekte ama ona tam anlamiyla bir "hiper-gerçeklik" sunmaktadır (Feyerabend, 2015: 15).

İngilizcede "alay etmek, aldatmak, taklidini yaparak eğlenmek" anlamlarını taşıyan "to mock" fiili ile "belgesel" manasına gelen "documentary" sözcüklerinin birleşimiyle oluşan "mockumentary" kelimesi, en geniş anlamda, "belgesel gibi görünen kurmaca yapıtları" karşılamak için kullanılmaktadır. Dilimize "sahte belgesel" olarak tercüme edilmiş olan sözcük, belgesel ve kurmacanın melez birlikteliğine gönderme yapmaktadır (Wallace, 2018: 5-6). ${ }^{9}$ Fakat spesifik olarak mokümanter bir filmin, kurmaca ile belgesel görüntüleri harmanlayan yarı-belgesel (semi-documentary) yapitlardan önemli bir farkı vardır. Mokümanter filmler, gerçekle kurmacanın sınırlarını özellikle; bile isteye bulanıklaştırmak isterler. Bu yolla anlatım gücünü yarı-belgesele nazaran çok daha fazla artıran mokümanter bir yapım (Sevim, 2019: 60), içerdiği yüksek oranda hiciv sayesinde bir yandan anlattı̆̆ meseleye dair ciddi bir eleştiri getirirken diğer yandan komedi türüne de yaklaşmaktadır (Miller, 2012: xi). Bununla birlikte, mokümanter bir film, nihayetinde, ne belgesel, ne kurmaca ne de komedi olarak tanımlanabilir; o, müphem bir biçemle varlığını sürdüren müstakil bir tür hâline gelir (Keskin, 2018).

Dolayısıyla, tıpkı hikâyesini anlattı̆̆ı kahramanın durumu gibi, Zelig filminin biçemi de kendisine başka bir şey süsü veren bir formdur: Belgesel gibi davranan bir kara-komedi. Bu yönüyle film, gerçekle kurmacanın, ciddiyetle komedinin sınırlarının devamlı aşıldığı özgün biçemiyle, çağdaş insanın uzunca bir süredir içinde bulunduğu ve Leonard Zelig'in hikâyesinde kendisini açık eden "göçerliğini", sıradan bir belgesel yahut komedi filmine göre çok daha etkili şekilde vurgulamaktadır. ${ }^{10}$

$\mathrm{Bu}$ anlamda, Allen'in belgeselle komedi olmak arasında mekik dokuyan müphem kimlikli filminin, biçimiyle, Leonard'ın şahsında tecelli eden "yer tutamayışımıza" son derece uygun düştüğü açıktır. Filmin hem kahramanı hem de anlatı yapısı "tereddütlü"

\footnotetext{
8 Annie Hall (1977) ve Manhattan (1979) filmlerinde de Woody Allen'la birlikte çalışan Gordon Hugh Willis, Zelig'teki performansı ile 1984 senesinde "En İyi Görüntü Yönetmeni” dalında Oscar'a aday gösterilmiş, yine aynı yıl “En İyi Görüntü Yönetmeni” ve “En İyi Görsel Efekt” dallarında BAFTA Ödüllerini kazanmıştır. Francis Ford Coppola'ya ait Baba Üçlemesi'nin (The Godfather, 1972, 1974 ve 1990) de görüntü yönetmenliğini üstlenmiş olan Willis'in, 1995 yılında Amerikan Görüntü Yönetmenleri Derneği tarafından "Yaşam Boyu Başarı” ödülüne layık görüldüğü de belirtilmelidir (https://www.imdb.com/name/nm0932336/?ref_=ttawd_awd_1).

${ }_{9}$ Bazı sinema çalışmalarında, kökeni Orson Welles' in 1938 yapımı Dünyalar Savaşı (The War of the Worlds) adlı radyo dramasına kadar geri götürülse de mokümanter filmlerin tam anlamıla 1960'lı yıllarda ortaya çıktığı söylenebilir. Yine bir Woody Allen filmi olan 1969 tarihli Parayı Al ve Kaç (Take The Money And Run) adlı yapım bu türün ilk örneklerinden biri olarak da kabul edilmekle beraber geniş bir izleyici kitlesiyle buluşmuş ilk mokümanter filmdir (Wallace, 2018: 8-10).

10 Göçerlik, burada, yaşadığımız çağın genel karakterini imleyen bir meta-kavram olarak insanın 19.yüzyıldan bu yana giderek derinleşen anlam krizine de vücut verecek şekilde "kendini yuvada hissetmenin imkânsız olduğu" bir dünyada yaşamasına gönderme yapmaktadır. Çağdaş insan fiziksel ve coğrafi anlamda değilse de, anlam dünyası ve değerler düzleminde zuhur eden bir evsizlikten; hem mekân hem de süre anlamında sonu gelmez bir mültecilikten mustariptir. Modern insan için artık bir var olma durumu halini almış olan göçerlik, "sürekli değişime maruz kalan dilde, tarihlerde ve kimliklerde ikamet etmeyi gerektirirken” (Chambers, 2014: 17) Leonard Zelig karakteri yalnızca mevcut durumun cisimleşmesidir.
} 
(reluctant) bir mahiyet arz etmektedir: Zelig' in benliğini başkalarından devşirmesi gibi, yapıt da anlatısını çeşitli türleri devamlı taklit ederek yahut bir janr'dan diğerine atlayarak; gerçek arşiv görüntüleri, (çoğu) gerçek kişilerle yapılmış düzmece röportajlar ve kurmaca çekimlerle örülmüş bir ilişkiler bağlamında inşa etmektedir (Bailey, 2001: 22-24). Kısacası, film bir montaj harikasıdır - tıpkı Zelig' in, daha doğrusu hepimizin benliği gibi.

\section{Modern Çă̆ımızın Fenomeni Olarak Bukalemun-İnsan}

Woody Allen'ın bu eseri, çeşitli alımlamaların kendine has perspektifleri ışığında farklı açılardan değerlendirilegelmiştir. Zelig'e dair çözümlemelerin dişavurumcu, psikolojik ve kültürel olmak üzere üç temelde inşa edildiğini söylemek mümkündür (Stam ve Shohat, 1987). İlk olarak Zelig, Woody Allen'ın kendi ikircikli sanat ve sinema anlayışının bir yansıması olarak ele alınmıştır. Auteur politikasının etki sahası içinde kalan bu tür çözümleme denemeleri, yalnızca Zelig'i değil, Amerikalı yönetmenin tüm filmografisini kendi sansasyonel kişiliğinin bir dişavurumu olarak görmektedir (Green, 1991: 74-75; Girgus, 2002: 1-19). İkinci olarak, Leonard Zelig karakterinin Lacan'c1 ayna evresini sağlıklı şekilde geçemeyen bir insanın parodisi olduğu savından hareket eden ve filmi "benlik" problemi üzerinden tartışmaya açan psikolojik analizler de bulunmaktadır (Feyerabend, 2015: 17). Son olarak, Leonard Zelig'in aşırı uyumcu olmak zorunda bırakılan benliği ile Yahudilerin tarih boyunca yaşadıkları ayrımcılık arasında bağ kuran kültürel kimi analizler de mevcuttur (Johnston, 2007: 297-298). ${ }^{11}$

Yapıta modern bireyciliğin ve öznelliğin yaşadığı kriz bağlamında bir açıklama getirmeyi amaçlayan çalışmamız açısındansa filmin kahramanı Leonard Zelig çağdaş insanın arketipi olup çıkmaktadır. Film, yazar ve eleştirmen Susan Sontag'ın (1933 - 2004) Leonard için sarf ettiği “O yirmili yılların fenomeniydi," sözünün ardından "Onun öyküsü medeniyetimizin tabiatını, zamanımızın özelliklerini yansıtır. Her ne kadar sadece bir insanın hikâyesi olsa da kültürümüzün bütün temalarını içeriyordu..." diyen sosyal teorisyen Irving Howe'un (1920 - 1993) düşünceleriyle başlamak suretiyle ana fikrini peşinen vurgulamaktadır. Zelig fenomeninde modern zamanların karakteristiğini görmek mümkündür. Onun hikâyesi bizimkinin abartılmış bir versiyonundan ibaretken, ortak öykümüz modern bireyciliğin serüveniyle şekillenmiştir.

Sıra dişı dönüşümleri sebebiyle hastaneye yatırıldıktan sonra medyanın ilgisini çeken Zelig'in hakkında çıkan sayısız gazete haberinden birinin başlığı da, bu bağlamda, dikkat çekicidir. Büyük punto ile "Kendisini dönüştüren insan keşfedildi" yazan başlık, modern bireyciliğin ve öznelliğin tarihine aşina olan herkese Rönesans'ta doğduğu müjdelenmiş “ne isterse o olabilen insanı" hatırlatacaktır. Modern bireyciliğe yapılan doğrudan atıf bununla da sınırlı değildir. Leonard'a, Dr.Fletcher tarafından verildikten sonra basın ve halk tarafından çok sevilen "bukalemun-insan" lakabı da dikkatlerden kaçmaz. İçten gelen bir kuvvetle dönüşme ve bu yolla her şarta uyum sağlama yeteneği ile herkesi şaşırtan Leonard

\footnotetext{
11 Filmin uzmanlarından Irwing Howe'un “Düşünüyorum da, bana göre [Zelig'in] hikâyesi Amerika'daki birçok Yahudi'nin deneyimini; bir insanın yerini bulup sonra da içinde yaşadığı kültüre uyum sağlama dürtüsünü yansıtıyordu," sözleri Leonard'ın bireysel öyküsünün ardında Yahudilerin tarih boyunca göğüslemek zorunda kaldıkları "daima yabancı olmak" deneyiminin de var olduğunu açık biçimde göstermektedir.
} 
Zelig karakteri, yukarıda sosyolog Zygmunt Bauman'dan alıntılayarak bahsettiğimiz Rönesans ütopyasının; bukalemun-insan'ın vücut bulmuş hâlidir.

Daha önce de belirtildiği üzere, Rönesans'la birlikte insan, yalnızca kendi aklı ve iradesiyle iyiyi kötüden ayırt edebilecek, özgürce yaptığ1 seçimleriyle de kendisini meydana getirebilecek bir varlık olarak öne çıkmaya başlamıştır (Cevizci, 2012: 227-228). Ferdin, bağımsız bir fail; hayatına bütünüyle yön vermeye muktedir biri olarak kabul edilmesinin ardından (Arkonaç, 2004: 254) bireyin özerklik talebi mutlaklaşmış ve günümüze kadar süren bir devamlılık arz etmiştir. Söz konusu talep, modernliğin ayırıcı vasıflarından biri olan liberal bireyciliği biçimlendiren etkenlerin başında gelirken (Küçük, 2011: 37) bu kültürel ruh içinde insan "göze çarpmak ve kendisini yerleşik biçimlerle mümkün olabileceğinden daha cömert ve dikkate değer biçimde sunmak istemiştir" (Simmel, 2009: 211). Bu bağlamda, modern dönemle birlikte persona' mız1 ${ }^{12}$ oluşturmak özgür ve bireysel bir çaba meselesidir; benlik, verili bir doğa ya da yazgı olmanın ötesine uzanarak reflektif bir tasarım hâlini almıştır. ${ }^{13}$

Buraya kadar anlatılanlar düşünüldüğünde, modern ülkülerle Zelig'in durumu arasında bir tezatlık var gibidir. Modernliğin talebi insanın kendi benliğini özgürce ve tüm yanlış inançlardan kurtulup sağlam biçimde inşa etmesi iken, Leonard Zelig geçici de olsa bir benlik inşa edebilmek için dahi başkalarına bağımlıdır. Hatta Leonard'ın hikâyesini anlatan dış sesin haber verdiği şekliyle o, "bir sıfır, bir gayri-insan, rol yapan bir ucube"dir. Dolayısıyla, modernliğin henüz yolun başında talep ettiği mutlak öznellikle Zelig'in müphem benliği arasında bir bağlantı kurmak mümkün değilmiş gibi görünebilir. Fakat modern bireyciliğin tarihi incelendiğinde, aradaki ilişkinin tezatlıktan çok devamlılık üzerine kurulduğu fark edilecektir. Rönesans'ın aşkın ve mutlak öznesi, modernlik kendi imkânlarının sınırlarına dayandığında, Jazz Çă̆ı'nın içkin ve müphem öznesine dönüşmüştür (Taylor, 2011: 9-11).

Sonunda yaratacağı güvensizlik ortamı sebebiyle mutlak öznenin yıkımını gerçekleştirecek ilk etmenlerden biri, modernliğin tam da temelinde olan bir nosyondur:

12 Latince "maske" anlamina gelen "persona" sözcüğü, İngilizcede "kişi” manasındaki "person" kelimesinin de kökenidir. Sözcügün orijinal anlamının 'maske' olması, basit bir rastlantı olmanın ötesinde, "herkesin her zaman ve her yerde, az çok farkında olarak belli bir rolü oynadığı gerçeğinin kabulü" ile ilgili olmak durumundadır. Üstelik bunda problemli bir yan da yoktur; insan hem kendini hem de başkalarını bu rollerin karşılıklı olarak ifa edilmesi sırasında tanır. Dolayısıyla, bu "rolün" oynanmasıyla cisimleşen "olmayı/dışa göstermeyi arzu ettiğimiz kişi", hakiki benliğimizin de bir performansı hâlini almaktadır (Park'tan Aktaran Goffman, 2014: 31). Elbette bu anlayışın modern döneme özgü olduğu açıksa da, benliğin akışkan/değişken bir dış çeper ile bu değişimi sağlıklı sınırlar içinde tutacak nispeten kararlı bir iç merkez olmak üzere iki katmanlı bir yapıya sahip olduğu söylenebilir. Bu ikili yapı, birbirinden yalıtılmış alanları değil, aksine, sınırlarını kesin anlamda belirlemenin mümkün olmadığı iki farklı algılama biçimini ifade etmektedir. Bu şekilde, her insan, farklı zamanlarda farklı roller üstlense bile benlik algısı parçalanıp gitmez; öz-varlığını bir ontolojik bütünlük içinde muhafaza edebilir ya da, tam tersi, tutarlı bir benlik algısına sahip olmasına rağmen değişime, başkalaşmaya müsait bir karakter arz edebilir (Fay, 2005: 24, 57; Arkonaç, 2012: 11).

13 Üstelik zamanla, dış görünüşün de kişiliğin doğal bir uzantısı olduğu fikrine ulaşılmıştır (Sennett, 2010: 202). Beden, içinde yaşadığımız fiziksel bir nesne olduğu kadar, öznelliğin sürdürülmesine imkân tanıyan "bir eyleme sistemi, bir praxis tarzı" olarak kabul edilir. Modernlik öncesinde dış görünüş, gelenek tarafından belirlenmiş ve büyük ölçüde standartlaştırılmış olup, kişisel olmaktan çok toplumsal kimliğin bir işareti olarak görülmüşse de, modern zamanlarda, "refleksif bir benlik tasarımının merkezi bir unsuru hâline gelmiştir" (Giddens, 2014: 132133). Buradan hareketle, filmde absürt biçimde verilmiş de olsa, yaşadığı her değişiminde Zelig'in diş görüşünün de farklılaşması anlamlıdır. 
Kuşku. Hatırlanacağı üzere, modernliğin felsefi kurucusu Fransız düşünür René Descartes'ın doğru bilgiye ulaşmak için kullandığ1 metodun özünü, mevcut tüm bilgilerimize hatta kendi varlığımıza bile yöneltmek durumunda olduğumuz radikal bir kuşku meydana getirmiştir (Descartes, 1644/2010: 49). Her şeyden şüphe edebilmesine rağmen kendi düşünen zihninden son derece emin olan modern ratio, bu haliyle, doğruluğu öznenin öz-kesinliği üzerine inşa etmiştir (Bumin, 2003: 54). Oysa ilginç biçimde, modern felsefi düşüncenin şekillenmesinde başat rolü oynamış olan kuşku, tek başına dahi, sonraki yüzyıllarda yaşanacak kaotik durumu açıklamak için yeterli görülebilir. Daha doğrusu, modern insanın tüm anlam/değer krizlerinin altında 'metodolojik kuşku'nun, yerini, 'ontolojik kuşku'ya bırakmasını bulmak mümkündür.

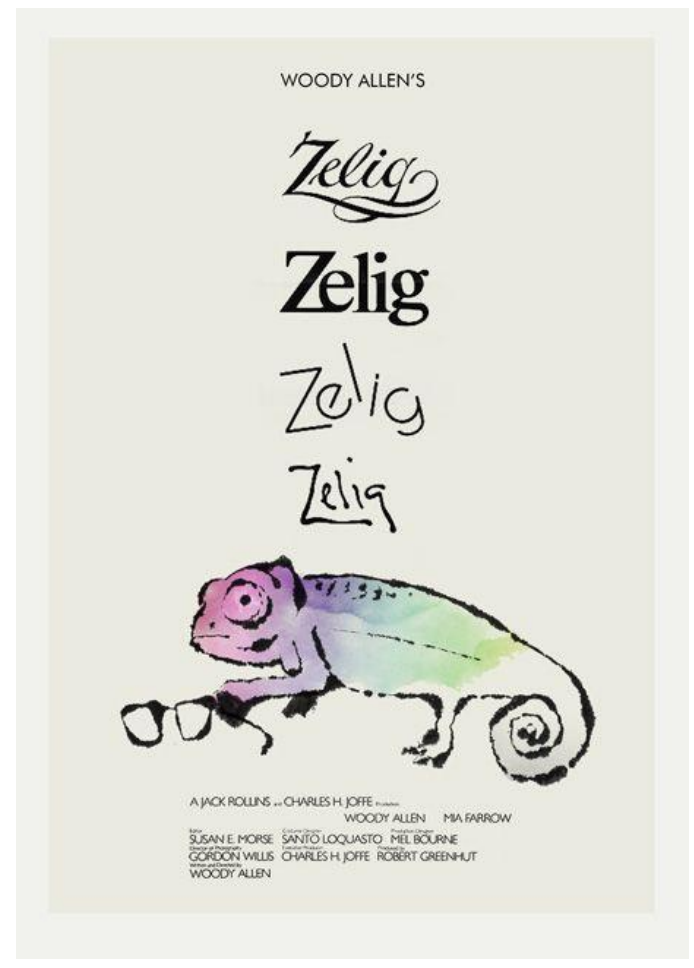

Görsel 2. Alternatif film afişi: Bukalemun-insan Zelig

Epistemolojik anlamda oldukça kullanışlı olan kuşkunun etkileri bireysel ve toplumsal dünyamızın genel varoluşsal boyutuna; gündelik hayatımıza nüfuz ettiğinde öngörülmeyen bazı problemler ortaya çıkmaya başlar. Modern aklın hareket noktası olan kuşku, kesin bilgiye ulaşmaktan; "spekülatif bilgi iddialarının yerine aklın kesinliğini" geçirmekten çok, ontolojik bir şüphe halini almaktadır çünkü radikal şüpheciliğin yolu bir kez açıldı mı tüm kesin bilgiler ve inanılan değerler sağlamlıklarını kaybetmektedirler (Giddens, 2014: 13, 110113). Bu açıdan, kuşkudan yola çıkılarak elde edilmiş sağlam bilgi zemininin ve zihinsel özgürlüğün ağır sayılabilecek bir faturası vardır. Söz konusu bedel her şeye yönelmeye başlayan ve kronikleşen güvensizliktir (Bauman, 2011a: 60).

Bir hipnoz seansı sırasında Zelig ve Dr. Fletcher arasında geçen;

- Kimsiniz siz?

- Ne demek istiyorsunuz? Bunlar zor sorular!

- Leonard Zelig mi? 
- Kesinlikle... Ama o kim?

diyaloğu modernliğin benlik üzerindeki baskısını ele vermektedir. Güvensizlik, muhakkak, benliğin kendisine de dönecektir. Marshall Berman'ın sözleriyle, "modern olmak, bizlere serüven, güç, coşku, gelişme, kendimizi ve dünyayı geliştirme olanakları vaat eden; ama bir yandan da sahip olduğumuz her şeyi, bildiğimiz her şeyi, olduğumuz her şeyi yok etmekle tehdit eden bir ortamda bulmaktır kendimizi" (2013: 27) ${ }^{14}$.

Önceki çağlarda özel bir çaba sarf etmeksizin deneyimlenen var olmak, modern dönemle birlikte kişisel gayret gerektiren bir belirlenim savaşı haline gelecektir. Burada, bireyin özgürlük ve isteme odaklı bir var olma durumuna yükseldiği ve seçme gücünün öne çıkartıldığı vurgulanırken, seçme gücünün bu kadar yüceltilmesinin kendi başına bir problem olabileceği hiç akla getirilmemektedir. Günümüzde bireyin özgür iradesi bir maksim haline gelmiştir gelmesine ama insanlar zamanlarının büyük kısmını yaptıkları seçimlerin doğruluğundan şüphe ederek geçirmektedirler (Twenge, 2013: 166). Dolayısıyla, özgürce yaptığımız seçimlerle inşa edildiğini düşündüğümüz kimliklerimizden kuşku duymamı; kim olduğumuzu bilemememiz gayet normaldir. Amerikalı psikiyatrist Erik Erikson (1902-1994) da "Günümüzün hastası daha ziyade neye inanması ve kim olması gerektiği -gerçekte kim olabileceği- veya kime dönüşebileceği problemlerinden mustariptir," demekle hepimizin benlikle ilgili yaşayabileceği patolojiyi özetlemektedir (Akt. Giddens, 2014: 95-96).

Yetmezmiş gibi, böyle bir şüphe ortamında, daha önce itimat edilebileceği düşünülen otoriteler de eski geçerliliklerini birer birer yitirirler. Bu anlamda, Zelig'e teşhis koymaya çalışan doktorların güvenilmezliği, otoritelerin sözüne ve uzmanlığına sırtımızı yaslayamayacağımız çağdaş dünyanın bir hicvi olarak karşımıza çıkmaktadır. Leonard'ın dönüşümleri sebebiyle şaşkınlık içinde olan hekimlerin durumunu bildirirken anlatıcı dış ses şöyle demektedir: "Doktorlar vakayı bütünüyle kavramaya çalışsa da kimse bir teşhis üzerinde görüş birliğine varamaz." Bütünsel bir dünyanın çoktan yok olduğu bir çağda bir fenomenin bütünüyle kavranması beklenemez de.

Bir doktor, sorunun Zelig'in salgı bezlerindeki bir problemden kaynaklandığını düşünmektedir, fakat salgı bezlerinde bir bozukluk olduğunu gösteren hiçbir bulgu olmadığını kendi de itiraf eder. Bir başkası, hastalığın kaynağının beyin tümörü olduğunu; Leonard'ın da tümör yüzünden birkaç hafta içinde öleceğini söylemektedir. Henüz yerini tespit edememişse de beyninde bir tümör olduğundan emindir. İronik şekilde, Zelig'e bir şey olmaz ama doktorun kendisi kısa süre içinde beyin tümöründen ölür. Hatta bir diğer doktor, saçma teoriler konusunda, Zelig'in Meksika yemeğinden kaptı̆̆ı bir "şey" (bu şey'in ne olduğunu söylemez) yüzünden bu hale geldiğini iddia edecek kadar ileri gider. Allen, ellerinde somut bir kanit olmamasına rağmen teorileri konusunda son derece katı olan doktorların durumunu olabildiğince gülünç şekilde verirken otoritelerin çaresizliğini ve kifayetsizliğini vurgulamaktadır. Güvenilmesi mümkün olmayan tıp otoritelerinin verdiği deneysel ilaçlar da Zelig'in durumunu iyileştirmez; daha kötüye götürür.

\footnotetext{
14 Vurgu tarafımızdan eklenmiştir.
} 


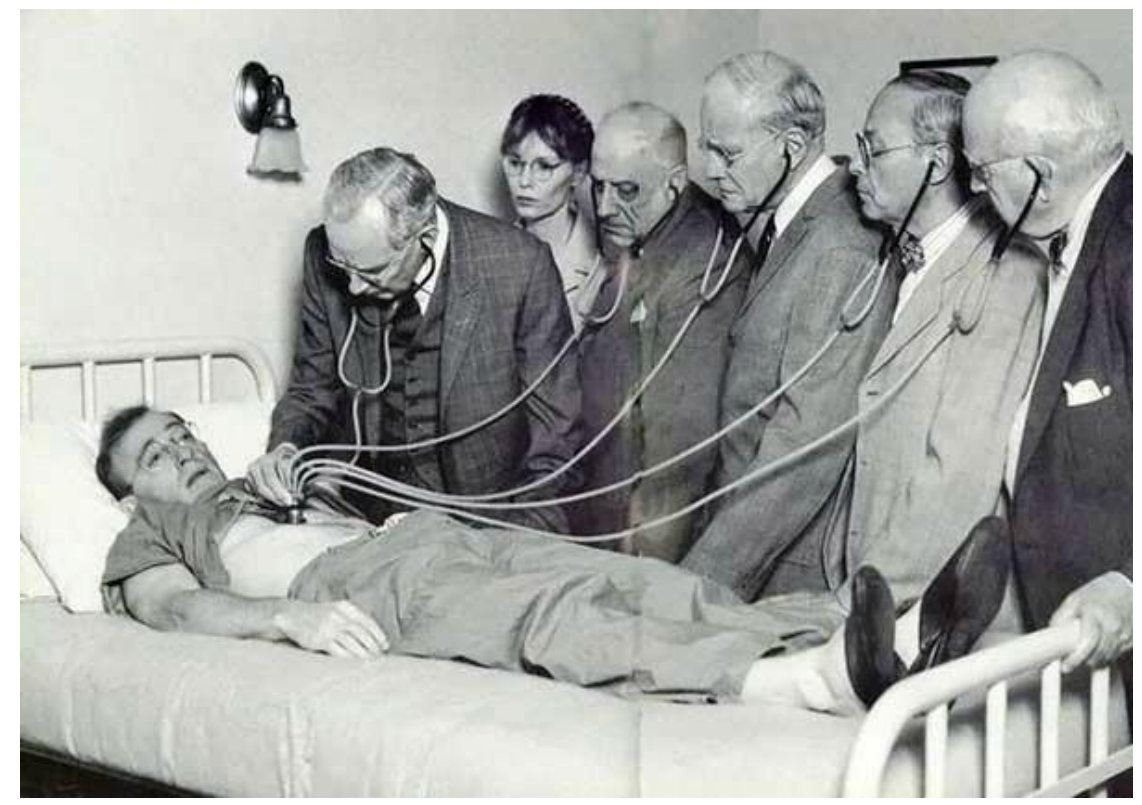

Görsel 3. Zelig ve ona ne olduğunu anlamaya çalışan doktorlar

Ayrıca, doğruluğun yalnızca insanın aklından hareketle ölçüldüğü bir dünyada siyaset, ekonomi, kültür, ahlak vb. alanlar da giderek özerkleştikleri gibi, her biri kendine özgü bir ussallık da üretir. Diğer bir ifadeyle, her özerk alanın doğruları ve yanlışları diğerinden farklı olma potansiyelini içinde taşır. Üstelik geleneksel toplum yapısından farklı olmak üzere, değer alanlarının özerk biçimde ürettikleri ussallık ve normları birbiriyle uyumlu hâle getirecek ve onlara hiyerarşik bir sıra düzen verecek ne teolojik (tanrısal) ne de teleolojik (amaçsal) bir üst anlatı ayakta kalabilmektedir (Weber'den akt. Atiker, 1998: 17, 23).

$\mathrm{Bu}$ atmosferde insanın kendisinden başka bir şeye inanma şansı yoktur (Simmel, 2010: 200). Fakat kendimize inanmak da bizi yeterince rahatlatmayabilir. Zira insanı merkez konumuna getiren metodolojik kuşku, ilk bakışta, onu köhnemiş boş inançlardan ve yersiz korkulardan özgürleştirmiş gibi görünse de, gizil (ya da Aydınlanma ile birlikte çok açı) biçimde ihtiva ettiği metafiziksiz bir varlık iddiası ile sonunda, bir değer varlığı olan insanı küçültmeye hatta tamamıyla yadsımaya mahkûmdur. Salt bir araç derecesine inmiş olan akıl, metafizik köklerini kaybettiği andan itibaren ruhsal ya da ahlâkî amaçlardan da yoksun kalmaktadır (Harvey, 2012: 57). Her alanda farklı işleyen ussallığı kendi bünyesinde anlamlı bir bütün haline getirecek bir üst anlatı kalmadığı gibi, farklı alanlarda farklı biçimde tezahür eden moral normları birbiriyle uyumlu kılacak herhangi bir ahlaki kaide bulmak da imkânsızlaşır. Böylelikle, her farklı ussallık ve norma uyum göstermenin kendisi -üstü örtülü de olsa- bir ahlaki kural haline gelir.

Zelig'in hipnoz halindeyken anlattığı bir çocukluk anısı metafizik köklerinden koparılmış aklın ve aşırı rasyonelleşmiş hayatın anlam/değer dünyamıza neler yapabileceğini izleyiciye trajikomik bir şekilde sunmaktadır. Hipnozluyken anlattığ hikâyeye göre, henüz 12 yaşında bir çocukken, Leonard bir hahama giderek hayatın anlamının ne olduğunu sorar. Haham varoluşumuzun anlamını söylese de cevabı İbranice verir. Leonard, İbranice bilmediği için cevabı anlamadığını söylediğinde ise haham Zelig'e 
600 Dolar karşıllı̆̆ında İbranice dersi vermeyi teklif eder. Görünen odur ki manevi dünyamıza yön verebilecek ruhani liderler bile modern çağın gerektirdiği şekliyle farklı ussallıklara uygun davranmakta bir sakınca görmemektedirler. Neticede, haham olmakla, para kazanmak zorunda kalmak başka şeylerdir. Aynı zamanda, bu hikâye izleyiciye şunları da hatırlatabilir: Bundan böyle bir ruhani lider bile bize hayatın anlamını söyleyemez, zira kendi de bütünsel bir anlam dünyasından kopmuştur. Belki daha da beteri, iyi niyetli şekilde bunu gerçekten yapmak istese bile söylediklerine bir anlam verebilmek bizim için mümkün değildir zira eskilerin hakikatleri modern rasyonalitenin pragmatik dilinde bir karşılık bulamaz.

Modernlik deneyiminin moral etkileri kadar, yine benliğimiz açısından bütünleştirici olmaktan ziyade dağıtıcı bir mahiyet arz eden fiziksel etkileri de bulunmaktadır. Söz konusu fiziksel etkiler modern şehir hayatının koşullarında karakter kazanan sosyal yapı ile ilgilidir. Yüzyıllar önce kendisini gösteremeye başlayan toplumsal dönüşüm, Sanayi Devrimi'nden sonra her gün büyüyen şehirlerle büyük bir ivme kazanmış ve geri döndürülemez bir hâle gelmiştir. Giderek büyüyen ve kalabalıklaşan şehirler içinde toplum, herkesin birbirine aşina olduğu ve gerçekten birlikte yaşadığı cemaatlerden (Gemeinschaft) değil, insanların çoğunlukla geçici organizasyonlar altında sınırlı süreyle toplandığı ve aralarında bireysel bir bağ olmaksızın yığınlar halinde bir arada yaşadıkları cemiyetlerden (Gesellschaft) oluşmaya başlamıştır (Pappenheim, 2002: 56-58). ${ }^{15}$ Oysa benlik, kendisini sağlıklı biçimde kurabilmek için görece tutarlı/sabit yahut değişim hızının ayak uydurabileceği ölçüde olacağı bir çevre talep etmektedir.

Geleneksel toplumlarda insanlar bir ömür boyu bir arada yaşadıkları insanlarla birlikte, diğerleri tarafından tanındıkları ölçüde kendi varlıklarını da tanıma şansı bulmuşlardır. Böyle bir sosyal yapının ortaya koyduğu duygulanım düzleminde, diğerleriyle ilişkinin sürekliliği ve açıklığı sebebiyle, kimlik açısından bir iç-dürüstlüğe ulaşmak da mümkündür. Buna karşın, modern yaşamda kişi, asla tam olarak tanımayı başaramadığı yabancılarla karşılaşmak, çalışmak ve yaşamak zorundadır. Böylece, modern şehir hayatında insanın sosyal kimliği, bireysel kimliğinden tedricen ayrışmaya başlar ve iki kimlik arasındaki yarılma öz varlığımızın da müphem olmasıyla sonuçlanır. Amerikalı psikolog William James'in dediği gibi “diğerleri seni bilmezken, senin de kim olduğunu bilmen zordur" (Elliot ve Lemert, 2011: 56). Benlik, ancak tanıma ve tanınma süreçlerinin hassas dengesi sayesinde tutarlı olabilecek bir yapı iken, kalabalık ve akışkan dünyamız ne başkalarını ne de kendimizi tanımaya fırsat vermektedir.

Hakikaten Zelig'in kendisinin kim olduğunu bilmemesi bir yana, kimsenin de Leonard'ın tam olarak kim olduğu hakkında bir fikri yoktur; dış ses'in tabiriyle "her bir Amerikalının kendine özgü bir yaklaşımı vardır." Bir adam, "Leonard Zelig, Amerika

15 Yeni toplum örgütlenmesi içinde insan topluluklarını karşılayan kavram kitle'dir. Kitle, 18. yüzyılın son çeyreği ile 19. yüzyılın ilk yarısı arasında yaşanan Sanayi Devrimi'nin koşulladığı endüstrileşme ile beraber, seri üretime katılmak için kalabalık şehirlerde toplanan ve benzer yaşam pratiklerine çaresiz bağlılıkları sonucu giderek tek tipleşen insanların oluşturduğu yığınları tanımlanmaktadır. "Kitle (kalabalık, yığın) kelimesi, basit ve sıradan anlamiyla, milletleri, meslekleri, cinsiyetleri ve kendilerini bir araya toplayan tesadüf her ne olursa olsun, rastgele bireyler topluluğunu ifade eder" (Le Bon, 2005: 23). Dolayısıyla, modernleşmenin insan yaşamı açısından ayırıcı vasfı bireyleşme değil, yığınlaşmadır (Gasset, 1992: 15-20). 
Birleşik Devletleri'ndeki en iyi insanlardan biridir. O harika biri!" demektedir. Bir başka kişiyse Zelig'in sıradışı yeteneğine öykünmekte ve bir gün onun gibi olabilmek istediğini söylemektedir. Bir hediyelik eşya dükkânında Çinli, entelektüel ve şişman Zelig'lere ait fotoğraflar satılmakta ve görüntülerden anlaşıldığı kadarıyla insanlar hangisini tercih ediyorsa onu satın almaktadır. Elbette, Zelig herkesin sempati duyduğu biri de değildir. Fanatikler için Leonard, eşitsizliğin ve adaletsizliğin simgesidir; bir mitingde konuşmacı “ $\mathrm{Bu}$ yaratık kapitalist insanı temsil ediyor. Sonuca ulaşmak için kılıktan kılığa giren bir yaratık..." der. Coşkulu hatibe göre Zelig'in arzu ettiği sonuç emekçilerin hileyle sömürülmesidir; mitingdeki bir pankartta da Zelig'in beş ayrı karakteri için beş ayrı işi çaldığı yazılıdır. Ku Klux Klan ${ }^{16}$ içinse Zelig, “zenciye ya da Kızılderili'ye dönüşebilen bir Yahudi olarak" üç kat nefret edilesi bir varlıktır. Zelig'in kimliğine dair hiçbiri birbirini tutmayan bu bakış açıları, onun tamamıyla anonimleştiğini göstermektedir -hem diğerleri hem de kendi için.

\section{Mükemmel Konformist Leonard Zelig}

Oysa Leonard Zelig yalnızca sevilmek, kabul görmek ve böylece bir topluluğa ait olmak isteyen zavallı bir yalnızdır, o kadar. Fakat başkalarınca kabul görmek için gerekli olan uyumun dozunu bir türlü ayarlayamadıkça, Zelig'in durumu patolojik bir hal almıştır. Dış sesin deyişiyle, “Zelig'in öz-varoluşu aslında bir var olmayıştır. İnsani nitelikleri o kadar uzun zamandır hayatın hengâmesinde kaybolmuştur ki kişilikten yoksun şekilde hep tek başına oturur, sessizce boşluğa bakarak... Bütün istediği uyum sağlamak, ait olmak, düşmanlarına görünmez olmak ve sevilmektir ama ne uyum sağlayabilir ne de aidiyet yaşayabilir."

Bir hipnoz seansı sırasında Dr. Fletcher ile Leonard arasında geçen şu konuşma da Zelig'in gerçekten yalnızca kendini koruma ve beğendirme güdüsü ile hareket ettiğini göstermektedir:

- Bana neden yanında bulunduğun insana benzediğini söyle.

- Çünkü bu güvenli.

- Güvenli ile neyi kast ediyorsun?

- Diğerleri gibi olmak güvenli.

- Güvende olmak $\mathrm{m} \mathrm{istiyorsun?}$

- Sevilmek istiyorum. ${ }^{17}$

Daha önce de değinildiği gibi, geleneksel yaşamı ve onun değerlerini ortadan kaldıran modernite, bireyi, bir zamanlar üyesi olduğu küçük toplumsal yapıların sağladığı maddi ve manevi destekten mahrum etmektedir. Güven duygusundan yoksun olduğu bir dünyada kendisini kaybolmuş ve yalnız hisseden birey ise (Giddens, 2014: 52) hayata öznelliği

\footnotetext{
16 "KKK" adıyla da bilinen Ku Klux Klan, 1865 yılında Amerika Tennessee'de kurulmuş, beyazların üstünlüğüne inanan, zenci ve göçmen karşıtı gizli ırkçı örgüttür. 1870'li yıllarda etkinliği azalan şiddet yanlısı ırkçı örgüt 1920'lerin başında yeniden yükselişe geçmiş ve Amerika Birleşik Devletleri'nin Güneybatısında gerçekleştirdikleri şiddet eylemleriyle tüm dünyada tanınmıştır. Büyük Buhran'la beraber üçüncü dönemine girmesinin ardından bir daha asla eski gücüne ulaşamasa da, örgütün halen 6.000 ile 10.000 arasında üyesi olduğu tahmin edilmektedir (McVeigh, 2009).

17 Zelig "I want to be liked." demektedir. İngilizcedeki "to be liked" kalıbının "sevilmek" kadar, "hoşa gitmek" ve

"kabul görmek" anlamlarını ihtiva ettiği unutulmamalıdır.
} 
çerçevesinde katılarak aktif bir fail olmaya değil, yalnızca "ayak uydurmaya” çalışacaktır. Bu anlamda, Leonard'ın babası Morris Zelig'in ölüm döşeğindeyken oğluna söylediği şu sözler derin bir anlam kazanır: "Hayat anlamsız, acı dolu bir kâbus; ipleri elinden bırakma!" Zelig de tam olarak bunu yapmaya; hayatının kontrolünü ne pahasına olursa olsun elinde tutmaya çabalamıştır. Filmde vurgulandığı üzere, "her ne kadar erkek kardeşi Jack sinir krizleri geçirse, kız kardeşi Ruth alkolik bir hırsız olsa da Leonard Zelig hayata ayak uydurmuş gibidir."

Zelig'in Jazz Çağı'nın baş döndürücü bir hızla akan hayatına ayak uydurabilmek için bulduğu çözüm her duruma mutlak bir uyum göstermek; kusursuz bir konformist (uyumcu) olmaktır. O'nun için benliğini devamlı olarak dönüştürmek, kendini koruma güdüsünden kaynaklanan bir savunma mekanizma olduğundan, psikiyatrist Eudora Fletcher, diğer doktorlara Leonard hakkındaki raporunu sunarken "Tabiatın kendisine içinde bulunduğu ortama uygun renklere bürünmek gibi bir koruyucu yöntem bahşettiği kertenkele misali, Zelig de kendisini etrafındaki her kimse ona dönüştürerek korumaktadır," diyecektir. Leonard, kendini koruma dürtüsüyle hareket etmekte; her şeyin akıp gittiği bir çağda oyunun dışında kalmamak için gerekli olan uyum yeteneğini kullanmaktadır.

Modern hayatta konformizm (uyumculuk), insanı güvensizlik duygusundan kurtarıcı bir rol üstlenmekteyken Leonard Zelig tek başına değildir; kendisine biçilen her rol ve yargıyla mücadele ederek kendisini gerçekleştirmeyi ülkü edinen modern öznenin, çağdaş zamanımızdaki son durağı radikal uyumculuk olmuştur. Birey, üzerindeki baskısını devamlı artıran rasyonalizm/kapitalizm/endüstriyalizm döngüsü içerisinde kendi hayatının üzerindeki kontrolünü kaybettikçe kitlenin içinde sürüklenmeye başlamakta; toplum da "heterenom -öteki tarafından yönetilen, rehberlik edilmekten çok itilen, yüzerek hareket etmekten çok plankton benzeri sürüklenen- bir hâle gelmektedir." Böyle bir durumda tüm fertler, kendilerine ve topluma bir yön vermeye çalışmaktan vazgeçerek genel akışa uygun davranmaya başlarlar ki çağdaş toplumlarda ihtiyatlı ve akılcı olmak da bunu gerektirmektedir. Bu açıdan, “özyönetimli ve özerk bir insanî dünya ile yaşanan modern çağların sonunda 'evrenselleştirilmiş uyum çağı' na girilmektedir" (Bauman, 2011a: 70-72).

Şimdiki önemli soru ise şudur: Zelig herkese benzemektedir ama herkes Zelig'e benzemekte midir? Dr. Fletcher'la yaptığı seanslardan birinde Zelig, başkaları gibi davranmaya, okuldaki zeki arkadaşları tarafından kınanmaktan korktuğu için, Herman Mellvile'in Moby Dick (1851) romanını okuduğuna dair yalan söylemesinin ardından başladığını söylemektedir. Hepimizin benzer kaygılarla bu türden manipülasyonlara başvurduğumuz itiraf edildiğinde bizim de Zelig'ten çok farklı olmadığımız meydana çıkacaktır (Feyerabend, 2015: 18). Zaten mokümanter yapımın gerçek uzmanlarından biri olan Amerikalı psikiyatrist Bruno Bettelheim da (1903 - 1990), modern insanla Leonard Zelig arasındaki yakınlığı şu sözlerle veciz biçimde ifade etmektedir:

"Zelig bir psikozlu muydu, yoksa nevrotik bir rahatsızlı̆̆ı mı vardı?" sorusu doktorlar arasında sonu gelmeyen düşüncelere yol açmıştır. Benim düşüncem onun normal insanlardan farklı olmadığı yönündeydi. Onun için belki pekâlâ uyumlu bir insan denebilir. Sadece bu uyumu uç bir noktaya taşımıştı. Onun, 'mükemmel konformist' olarak algılanacağını düşünmüştüm." 
Diğger yandan, kalabalıkların ve ona uyum göstermenin de özne üzerinde önemli bir teskin edici etkisi olduğu hatırda tutulmalıdır. Birey, kitle içinde diğerleriyle aynılaşırken, modern bireyciliğin ona dayattığı yalıtılmışlıktan da kurtulmaktadır (Fromm, 2011: 114). Kişi, kalabalıklar içinde "bir tür rahatlama hisseder çünkü onu kendisine döndüren ve içine kapatan mesafeler artık aradan kalkmıştır" (Canetti, 2014: 19). Diğer bir deyişle, birey kalabalıklar içinde erimekle; bireysel varlığını tamamen yadsımakla uyumculuğun nihai noktasına varmaktadır. Bu anlamda, farklı kimlikler altında farklı kadınlarla evlendiği ortaya çıktığı zaman Amerika'da bir canavar ilan edilip kimse tarafından kabul görmediğinde, Leonard'ın herkesin aynı düşünmek ve davranmak durumunda olduğu Nazi Almanya'sına kaçması oldukça anlamlıdır. Yazar Saul Bellow'un (1915 - 2005) "her ne kadar sevilmek için can atsa da, onda topluluk içinde yok olmayı, anonimleşmeyi arzulayan bir yan da vardı. Faşizm, Zelig'e bu alternatifi sunuyordu. Bu büyük harekete katılıp, anonimleşecek bir şeyler yapabilirdi," sözleri Zelig'in şahsında, belirsiz ve yalıtılmış bir öznelliktense, özgürlüğümüz pahasına da olsa belirlenmiş ve bize aidiyet hissi sunacak bir kolektiviteye nasıl bağlandığımızı açık biçimde anlatmaktadır. ${ }^{18}$

Tam bu noktada karşımıza başka bir pencere daha açılmaktadır. Uyum ve çatışma dengesinin kurulması modern birey için başlı başına bir problemken, sorunun kaynağında yine modernliğin müphem öznelliği bulunmaktadır. Aşırı uyum sağlamakla sağlıklı bir benlik inşa edilemeyeceğini anlayan insanın, sabit fikirlerle ördüğü bir anlam dünyası içinde aşırı merkezlenmesi de diğer bir vakıadır. Zelig film boyunca her iki durumu da deneyimlemektedir. Önce kendi fikrini asla söyleyemeyen ve başkalarının fikirleriyle uyumlu olmak için kendisini devamlı suretle değiştiren Zelig, tedavi sürecinde giderek aşırı merkezlenmeye başlar.

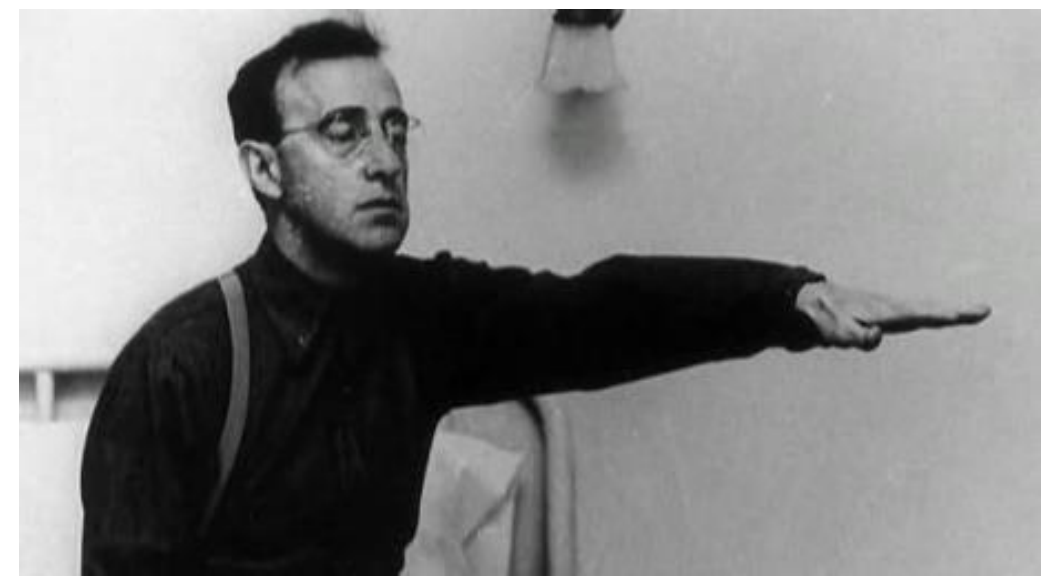

Görsel 4. Leonard Zelig hipnozun etkisi altında

\footnotetext{
18 Psikolog Eric Fromm, Özgürlükten Kaçış adlı eserinin “Nazizm Psikolojisi” adlı bölümünde (2011: 167-191) insanın kitleye coşkuyla katılımının hangi psikolojik dinamikler uyarınca gerçekleşebileceği meselesini Almanya özelinde tartışırken karşımıza çıkan bir detay dikkatimizi çeker. Fromm, Adolf Hitler'in Kavgam (1925) adlı kitabında, gençlik dönemi boyunca kendisini "bilinmeyen adam" ya da "hiç kimse" olarak tanımladığının altını çizmektedir (2011: 175). Hatırlanacağı üzere, Leonard Zelig de filmin anlatıcı dış sesi tarafından "sıfır" yahut "gayri-insan" olarak tarif edilmiştir. Ayrıca, hipnoz altında geçirdiği zamanlarda Leonard hep Nazi selamı verir şekilde durmaktadır (bkz. Görsel 4). Hitler ve Zelig arasında özellikle kurulduğunu söyleyebileceğimiz bu türden anıştırmaların, modern öznenin uyumculukla parçalanmış karakteri ile onun "merkezlenme" çabaları arasındaki ikircikli ilişkiyi vurgulamaya dönük olduğu iddia edilebilir (Papson, 2013: 162-166) .
} 
Tedavi sürecinin ilk safhalarında her şey yolunda gibidir. Zelig, seans sırasında "Kendin olmalı ve kendi ahlaki seçimlerini yapmalısın... Cesaret gerektirse de... Yoksa bir robot ya da kertenkele olursun," derken sağlıklı bir benlik inşa etmiş gibi görünmektedir. Fakat zamanla Leonard aklından geçenleri giderek daha cesur şekilde söylemekle kalmaz, bir noktadan sonra, fikrini ifade ederken sergilediği fütursuzlukla kabalaşarak genel nezaket kurallarına dahi uymaz olur. Leonard'ın fikrini ifade etme cesareti önce kabalığa, ardından da saldırganlığa varacaktır.

Dr. Eudora Nesbitt Fletcher'ın sürdürdüğ̈ü özel seansların ne aşamaya geldiğini merak eden doktorlar Zelig'i ziyarete geldiklerinde de ilk başta her şey yolunda gitmiş, etrafı onca psikiyatristle çevrili olmasına rağmen Leonard onlardan birine dönüşmemiştir. “Görünüşe göre, ortada çok büyük bir başarı vardır, ta ki Dr. Mayerson masumane bir şekilde hava durumundan söz açıp güzel bir gün olduğu yorumunu yapana kadar." Leonard, havanın güzel olduğu konusunda doktorla aynı fikirde olmadığı için onunla tartışmaya başlar, "kişisel düşüncelerini korkusuzca dile getirme eğitimi almış olan Zelig'in tutumu saldırgancadır." Sonunda doktoralara gerçekten saldırır ve onları tırmıkla döver. Anlatıcının da söylediği gibi "şimdi de aşırı-fikirlenmiştir; kendisiyle uyuşmayan herhangi bir fikre tahammül edememektedir."

Bu açıdan, ilk bakışta karşıtlık ilişkisi içindeymiş gibi görünseler de aşırı uyumcu bir hal içinde devamlı uzlaşımcı olmakla, radikal biçimde merkezlenerek başkalarına hiç uyum göstermemek arasında özne açısından büyük bir fark yoktur: Her ikisi de modern öznelliğin müphemliğinin doğal sonucu olarak görülebilir. Benliğin, "kendi" ile "öteki" arasında kurulan sağlıklı bir ilişkinin neticesinde ortaya çıktığını (Crary, 2015: 30) anlayamayan her kişi, ya kendinden nefret ederek devamlı öteki olmaya çabalayacak ya da kendini, öteki'nden nefret ederek var etmeye çalışacaktır.

\section{Sonuç}

Modernlik, öznelliğimiz açısından paradoksal bir durum meydana getirmiş; bir yandan kim olmak istiyorsak o olmak konusunda bizi özgür bırakırken, diğer yandan da tutarlı/sabit bir benlik geliştirebilmemiz için gerekli olan tüm maddi ve manevi payandaları teker teker yıkmıştır. Bunun sonucunda insan, kendisini hem özgür hem de güvende hissedeceği bir dünyaya ulaşmak yerine, ne özgür ne de güvende hissedebildiği bir kargaşa durumuna düşmüştür. Yalnızca modern toplumlarda görebileceğimiz üzere, talep edilen özgürlük ile ihtiyaç duyulan güvenlik arasındaki uzlaşmazlık üzerimizde büyük bir baskı yaratmaktadır. Fakat böyle bir atmosfer içinde, her şeyin tam da kendi karşıtına döndüğü bir zamanda "birey, birey olmaya kalkışır" (Berman, 2014: 37).

Fakat modern birey, ulaşılan bir başarıdan ziyade, bir zamanlar kurulan bir hayalden artakalan şeydir. Diğer bir deyişle, belirsiz ve içkin bir varlık olarak "birey" (individual), Rönesans düşüncesinin mutlak ve aşkın bir ortak değer olarak tanıdığı "insan"ın (human) çağlar içinde giderek küçülmesiyle ortaya çıkmıştır. Woody Allen'ın 1983 tarihli filmi Zelig'teki kahramanımız Leonard da, modern cogito'nun merkezi olan ve her şeyi yapmaya muktedir evrensel insanı değil; büyük anlatıların yıkıldığı, kalabalık şehirlerde kimsenin 
birbirini tanımadığı, herkesin farklı ussallık alanlarında farklı ahlaki normlara uygun davranmak zorunda kaldığı bir dünyanın yalnız bireyidir.

Kiminle olsa ona benzemesinin, hangi ortama girerse oraya uyum sağlamasının yahut tam tersi, kalabalıklar arasında yok olup gitmeye çalışmasının altında kendini koruma güdüsü yatmaktayken, Zelig'in benliğini bu denli esnek kılan şey modernliğin akışkan/müphem öznelliğinden başkası değildir. Baudrillard, gerçek anlamda derinleşmenin, yer tutabilmenin mümkün olmadığı, her şeyin bir yüzey ve görünüm meselesi haline gelerek hızla akıp değiştiği çağdaş dünyamızda "insanın kaybolduğunu; kendini somut olmayan bir öznelliğe teslim ettiğini" söylerken (2012: 40), Leonard da "özgürce" değiştirdiği maskelerinin ardında anonimleşen bir insanın portresini çizmektedir.

Kimlikten kimliğe ve bir yerden diğerine durmaksızın göçmek zorunda olan modern bukalemun-insanın serüveni, Amerikalı yönetmen tarafından, türler arasındaki sınırı devamlı ihlal etmesiyle meşhur bir film biçimi olan mokümanterle izleyiciye aktarılmıştır. Komedinin kendini bir belgesel gibi sunması, gerçekle kurgunun kolayca ayrılamayacak ölçüde birbirine karışması, bir anlamıyla, Leonard'ın hikâyesinin tamamen kurmaca olmadığına da gönderme yapmaktadır. Sevilmek, kabul görmek yahut güvende hissetmek için kimliğini devamlı değiştiren ve uyum sağlayamaya çalışan Leonard her an bize benzeyebilirken, onunla paylaştığımız tarihe ve şartlara olan aşinalığımız bizim de her an ona benzeyebileceğimizi hatırlatmaktadır.

Son olarak, filmin mutlak karamsar bir bakışa sahip olduğu söylenemez zira kahramanımız nihayetinde normale dönecektir. Leonard Zelig, mükemmel konformist olmakla aşırı merkezlenmek arasında gidip gelirken, onu her iki hastalıklı tavırdan da kurtaran tek şey Dr. Eudora Fletcher'ın ilgisidir. Diğer tüm doktorlar, medya, halk ve hatta ünlü bir isim olmasından sonra birden ortaya çıkan ailesi bile Leonard'la araçsal bir ilişki kurmuş, bu sebeple Zelig bunlardan hangisine doğrudan ya da dolaylı biçimde temas etse sonucu tam bir fiyasko olmuştur. Oysa Dr. Fletcher kahramanımızla gerçekten ilgilenir; Eudora'nın Leonard'la kurduğu, karşılıklı sevgi ve merhamete dayalı ilişki araçsal olmaktan uzaktır. Modern zamanların akılcılığının ve ihtiyatlı yaşamının kendisine veremediği dengeli bir özgürlük durumunu, Zelig'e, öteki ile girdiği sağlıklı bir iletişim sunacaktır. Dolayısıyla, Woody Allen, bizim için hâlâ bir ümit olduğunu söylemek ister gibidir: Birbirimizle kuracağımız gerçek bağlar hepimizi iyileştirebilir.

\section{Kaynakça}

Arkonaç, A., S. (2012). Psikolojideki Özne Kavramı ve Türkiye'deki Özne Kavramı Üzerine Bazı Düşünceler. Sosyoloji Dergisi, 3(7), 11-22.

Atiker, E. (1998). Modernizm ve Kitle Toplumu. Konya: Vadi Yayınları.

Arslan, İ. (2012). Çağdaş Doğa Düşüncesi. İstanbul: Küre Yayınları.

Baudrillard, J. (2012). Neden Her Şey Hâlâ Yok Olup Gitmedi?. (Çeviren: Oğuz Adanır). İstanbul: Boğaziçi Üniversitesi Yayınları. 
Bailey, J., P. (2001). The Reluctant Film Art of Woody Allen. Kentucky: The University Press of Kentucky.

Bauman, Z. (2003). Modernlik ve Müphemlik. (Çeviren: İsmail Türkmen). İstanbul: Ayrintı Yayınları.

Bauman, Z. (2011a). Postmodern Etik (2.Baskı). (Çeviren: Alev Türker). İstanbul: Ayrıntı Yayınlar1.

Bauman, Z. (2011b). Bireyselleşmiş Toplum (2. Baskı). (Çeviren: Yavuz Alogan). İstanbul: Ayrıntı Yayınları.

Bumin, T. (2003). Tartışılan Modernlik: Descartes ve Spinoza (2. Baskı). İstanbul: Yap1 Kredi Yayınları.

Cannetti, E. (2014). Kitle ve İktidar (6. Baskı). (Çeviren: Gülşat Aygen). İstanbul: Ayrıntı Yayınları.

Cassirer, E. (2008). Rönesans Felsefesinde Birey ve Evren. (Çeviren: Emre Can Ercan). Bursa: Verka Yayınları.

Cevizci, A. (2012). Felsefenin Kısa Tarihi. İstanbul: Say Yayınları.

Chambers, I. (2014). Gö̧̧, Kültür, Kimlik (2. Baskı). (Çevirenler: Mehmet Beşikçi ve İsmail Türkmen). İstanbul: Ayrıntı Yayınları.

Crary, J. (2015). 7/24: Geç Kapitalizm ve Uykuların Sonu (Çeviren: Nedim Çatlı). İstanbul: Metis Yayınları.

Çotuksöken, B. (2002). Felsefe: Özne - Söylem. İstanbul: İnkılâp Yayınları.

Descartes, R. (1644/2010). Felsefenin İlkeleri (12. Baskı). (Çeviren: Mesut Akın). İstanbul: Say Yayınları.

Elliot, A. Ve Lemert, C. (2011). Yeni Bireycilik: Küreselleşmenin Duygusal Bedelleri. (Çeviren: Başak Kıcır). İstanbul: Düşünsel Yayınları.

Fay, B. (2005). Çağdaş Sosyal Bilimler Felsefesi (2. Baskı). (Çeviren: İsmail Türkmen). İstanbul: Ayrıntı Yayınları.

Feyerabend, B. (2015). "Zelig: A Simulated Life". Referantiality and the Films of Woody Allen (Edited by Klara Stephanie Szlezák and D. E. Wynter). New York: Palgrave MacMillan.

Fromm, E. (2011). Özgürlükten Kaçış (6. Baskı). (Çeviren: Şemsa Yeğin). İstanbul: Payel Yayınları.

Gasset, y O. (1990). İnsan ve "Herkes" (2. Baskı). (Çeviren: Neyyire Gül Işık). İstanbul: Metis Yayınları.

Giddens, A. (2014). Modernite ve Bireysel-Kimlik: Geç Modern Çă̆da Benlik ve Toplum (2. Baskı). (Çeviren: Ümit Tatlıcan). İstanbul: Say Yayınları.

Girgus, S. (2002). The Films of Woody Allen. London: Cambridge University Press. 
Goffman, E. (2014). Günlük Yaşamda Benliğin Sunumu (3.Baskı). (Çeviren: Barış Cezar). İstanbul: Metis Yayınları.

Green, D. (1991). The Comedian's Dilemma: Woody Allen's 'Serious' Comedy. Literature/Film Quarterly, 19(2), 70-76.

Guénon, R. (1999). Modern Dünyanın Bunalımı (2. Baskı). (Çeviren: Mahmut Kanık). İstanbul: Verka Yayınları.

Harvey, David. (2012). Postmodernliğin Durumu (6. Baskı). (Çeviren: Sungur Savran). İstanbul: Metis Yayınları.

Johnston, D., R. (2007). Ethnic and Discursive Drag in Woody Allen's Zelig. Quarterly Review of Film and Video, 24(3), 297-306.

Karaduman, S. (2010). Modernizmden Postmodernizme Kimliğin Yapısal Dönüşümü. Journal of Yaşar University. 17(5), 2886 - 2899.

Keskin, B. (2018). “Evet, Dalga Geçiyoruz!: Mockumentary Nedir, Ne Değildir?”. Film Hafizast. https://www.filmhafizasi.com/evet-dalga-geciyoruz-mockumentary-nedir-nedegildir. Son erişim tarihi: 29.12.2019.

Küçük, M. (2011). "Postmodernin Modern Karakteri ya da Dönemleştirmenin İronisi”. Modernite versus Postmodernite. (Editör: Mehmet Küçük). İstanbul: Say Yayınları, 27-64.

Küçükalp, K. ve Cevizci, A. (2009). Batı Düşüncesi: Felsefi Temeller. İstanbul: İsam Yayınları.

Le Bon, G. (2005). Kitleler Psikolojisi (3. Baskı). (Çeviren: Selâhattin Demirkan). İstanbul: Yağmur Yayınları.

Levi, A., W. (2002). "Modern Felsefe". (Çeviren: Ahmet Cevizci). Felsefe Tarihine Giriş. (Editör: Ahmet Cevizci). İstanbul: Paradigma Yayınları, 73-134.

McVeigh, R. (2009). The Rise of the Ku Klux Klan: Right-Wing Movements and National Politics, Mineapolis: University of Minnesota Press.

Miller, J., C. (2012). To Bold for the Box Office: The Mockumentary from Big Screen to Small. (Edited by Cynthia J. Miller). Plymouth: The Scare Crow Press.

Mirandola, Giovanni Pico della. (1496/1956). Oration on the Dignity of Man (3rd Printing). (Translated by A. Robert Caponigri). Chicago: Henry Regnery Company.

Pappenheim, F. (2002). Modern İnsanın Yabancılaşması: Marx'a ve Tönnies'ye Dayalı Bir Yorum. (Çeviren: Salih Ak). Ankara: Phoenix Yayınları.

Papson, S. (2013). "Critical Theory and the Cinematic World of Woody Allen". A Companion to Woody Allen (Edited by Peter J. Bailey and Sam B. Girgus). West Sussex: WileyBlackwell.

Wallace, R. (2018). Mockumentary Comedy: Performing Authenticity. London: Palgrave McMillan. 
Sennett, R. (2010). Kamusal İnsanın Çöküşü (3. Bask1). (Çeviren: Serpil Durak ve Abdullah Yılmaz). İstanbul: Ayrıntı Yayınları.

Sevim, S. (2019). The War Game: Sahte Belgesel Gerçek Endişe. Kritik İletişim Çalışmaları Dergisi, 1(2), 57-78.

Simmel, G. (2009). Bireysellik ve Kültür. (Çeviren: Tuncay Birkan). İstanbul: Metis Yayınları.

Stam R. ve Shohat, E. (1987). Zelig and Contemporary Theory: Meditation on the Chameleon Text. Enclitic, 9(12 -Fall), 176 - 193.

Streissguth, T. (2007). The Roaring Twenties, Revised Edition. New York: Facts on Files Inc.

Tarnas, R. (2011). Batı Düşüncesi Tarihi II. Cilt. (Çeviren: Yusuf Kaplan). İstanbul: Külliyat Yayınları.

Twenge, M., J. (2013). “Ben” Nesli: Bugünün Gençleri Niçin Bu Kadar Özgüvenli ve İddialı Fakat Bir O kadar da Depresif ve Kaygılı? (4. Baskı). (Çeviren: Esra Öztürk). İstanbul: Kaknüs Yayınları.

-------, “Gordon Hugh Willis'in Biyografisi, Filmografisi ve Kazandığı Ödüller”, https://www.imdb.com/name/nm0932336/?ref_=ttawd_awd_1. Son erişim tarihi: 2.01.2020.

---------, "Zelig", https://www.collinsdictionary.com/dictionary/english/zelig. Son erişim tarihi:

12.01.2020. 